\title{
Междисциплинарное исследование растительных остатков в древнерусском кладе
}

Бабиченко Н.П.*, Пожидаев В.М., Яцишина Е.Б.

Национальный исследовательский иентр «Курчатовский Институт», Москва, Россия

*e-mail: babichenko28@gmail.com

Ключевые слова: ладан, газовая хроматография, босвеллиевые кислоты, масс-спектрометрия

Мотивация и цель: Изучение древних реликвий с использованием современных естественнонаучных методов значительно расширяет возможности получения уникальной информации, в том числе, в области христианской археологии и позволяет разработать надежные подходы к идентификации их содержимого. В рамках работы по изучению средневековых христианских древностей Суздальского Ополья (Владимирская область), рабочей группой НИЦ «Курчатовский институт» было проведено исследование археологического образца ладана из фондов ВладимироСуздальского музея.

Meтоды и алгоритмы: Методом ГХ/МС в испытуемом образце обнаружены соединения, которые входят в состав современных образцов ладана: 3 -эпи-лупеол, $\beta$-амиренон, $\alpha$ - и $\beta$-амирины, но отсутствовали основные биомаркеры - босвеллиевые кислоты и их ацетилированные производные. Кроме этого, в образце музейного ладана обнаружены 24-норолеан-3,12-диен, 24-норурса-3,12-диен и 4-норлупа-3,20(29)-диен. Эти компоненты являются известными продуктами термического разложения ладана [1-4]. Для исследования наличия пчелиного воска, остатки исследуемого образца после растворения в метаноле подвергали экстракции гексаном. Полученный экстракт анализировали методом ГХ/МС.

Результаты: По результатам проведенного исследования сделан вывод, что музейный образец представляет собой смесь остатков ладана из кадильницы после церковного богослужения и пчелиного воска.

Заключение и доступность: Археологический контекст находки позволяет высказать гипотезу о возможном отношении ее хозяина к изготовлению «воскомастики» из остатков ладана и воска для фиксации вложений-реликвий и створок крестов-энколпионов.

Благодарности: Авторы выражают благодарность главному хранителю ФГБУК «Государственный Владимиро-Суздальский историко-архитектурный и художественный музей-заповедник» Курниковой И. В. за предоставленный для исследований музейный образец.

Список литературы

6. Michael P. et al. A Thin-layer Chromatography Method for the Identification of Three Different Olibanum Resins (Boswellia serrata, Boswellia papyrifera and Boswellia carterii, respectively, Boswellia sacra). Phytochemical Analysis. 2012;23(2):184-189.

7. Mathe C.et al. Characterization of archaeological frankincense by gas chromatography-mass spectrometry. Journal Chromatography. 2004;1023(2):277-285.

8. Evershed R.P., et al. Archaeological frankincense. Nature. 1997;390(6661):667-668.

9. van Bergen P.F. et al. Chemical evidence for archaeological frankincense: Boswellic acids and their derivatives in solvent soluble and insoluble fractions of resin-like materials. Tetrahedron Letters. 1997;38(48):8409-8412. 